DEPARTAMENTO DE MICROBIOLOGIA E IMUNOLOGIA

Diretor: Prof. Dr. Paulo M. G. de Lacerda Júnior

\title{
ESTUDO SOOBRE MICROCOCCUS PYOGENES DE MASTITE BOVINA
}

(STUDY ON MICROCOCCUS PYOGENES FROM BOVINE MASTITIS)

\section{LUIZ ZaNI NETO}

Assistente

O estudo dos Micrococcus pyogenes apresenta real importância em patologia, uma vez que tais germes se constituem em agentes etiológicos de toxi-infecções ou de infecçōes graves.

No decorrer de pesquisas sôbre mastite bovina, realizadas neste Departamento, pudemos observar que grande número dessas infecçōes era produzido por Micrococcus pyogenes. Dai o interêsse em estudarmos, comparativamente, as diferentes propriedades das amostras de estafilococos isolados em tais processos.

Pesquisámos simultâneamente a produção de hemolisinas $\alpha$ e $\beta$, a coagulação do plasma oxalatado, a fermentação da manita, a produção de pigmento e a fusão da gelatina, cujos resultados são apresentados neste trabalho.

\section{MATERIAL E MÉTODO}

Foram estudadas 73 amostras de Micrococcus pyogenes obtidas da secreção mamária de vacas portadoras de mastite.

A coleta do material em frascos esterilizados, com a capacidade de $20 \mathrm{~cm}^{3}$, foi feita após desinfecçāo da porção terminal dos têtos, com solução de álcool-éter iodado. Essas amostras foram semeadas em caldo simples e incubadas a $37^{\circ} \mathrm{C}$, por 24 horas.

Comprovada a presença de estafilococos, em esfregaços corados pelo Gram, para o seu isolamento, as culturas obtidas foram semeadas em placa de agar com $5 \%$ de sangue desfibrinado, de carneiro.

Os métodos utilizados para as pesquisas acima referidas foram os seguintes:

1) Hemólise em placa de agar-sangue - Esta caracteristica foi por nós pesquisada segundo a orientação dos trabalhos de MINETT (1937). 
Uma alça de platina de uma cultura de 18 horas em caldo triptose (Difco. B 62) foi repicada em placa de agar triptose (Difco. B 64) contendo $5 \%$ de sangue desfrinado, de carneiro. As placas semeadas foram incubadas a $37^{\circ} \mathrm{C}$, em atmosfera contendo $30 \%$ de $\mathrm{CO}_{2}$, durante $3 \hat{3}$ horas, sendo a seguir transferidas para um refrigerador a $4^{\prime \prime} \mathrm{C}$, onde permaneciam uma noite.

Aquelas amostras que produziam sòmente hemolisina $\alpha$ apresentavam ao redor da colônia uma zona clara, de contornos mal delimitados, de hemólise total e sem nenhum sinal de progresso, após refrigeração por uma noite.

As amostras, que produziam ùnicamente a $\beta$ lisina, mostravam uma zona escura de contornos bem delimitados, de hemólise parcial, que se acentuava quando transferida para o refrigerador. As que produziam $\alpha$ e $\beta$ lisinas mostravam uma zona de hemólise total circundada por uma zona de hemólise parcial.

2) Produção e dosagem das hemolisinas - De acôrdo com o método descrito por DoLManN (1935), a toxina foi preparada cultivando-se a. amostra em agar semi-sólido, com $0,3 \%$ de agar.

Frascos de Erlenmeyer foram semeados e incubados durante 44 horas a $37^{\circ} \mathrm{C}$ em atmosfera contendo $30 \%$ de $\mathrm{CO}_{2}$.

Os testes quantitativos das hemolisinas foram feitos segundo o critério proposto por MAC FARLAND (1938). Após a filtração das culturas em papel de filtro, no refrigerador, duas séries de 6 diluições variando de 1:1 a 1:80 foram preparadas em solução fisiológica. Cada tubo continha um volume final de $1 \mathrm{ml}$. A cada tubo da primeira série foi adicionado $0,1 \mathrm{ml}$ de uma suspensão a $10 \%$ de glóbulos lavados, de coelho, e a cada tubo da segunda série foi adicionada uma suspensão de glóbulos de carneiro, nas mesmas condições.

Os tubos permaneciam em banho-maria a $37^{\circ} \mathrm{C}$ por uma hora, quando a primeira leitura foi feita, sendo em seguida transferidos para o refrigerador por uma noite, para a leitura final.

O título final foi tomado pela maior diluição da hemolisina capaz de lisar no mínimo $50 \%$ dos glóbulos.

Para aquelas hemolisinas capazes de lisar totalmente atẻ a diluição de 1:80, foi preparada uma nova série de 7 diluiçōes variando de 1:100 a $1: 1200$. 
A hemólise dos glóbulos de coelho indicava a presença da hemolisina a e a hemólise dos glóbulos de carneiro, após refrigeração, era indicativa da $\beta$ lisina.

3) Coagulase - A demonstração da coagulase foi feita segundo o método descrito por THoMpson e KHoroza (1937). Sangue fresco de coelho, oxalatado a $0,2 \%$, foi centrifugado para separar o plasma, o qual foi misturado, em pequenos tubos, a uma cultura de 18 horas, em caldo triptose (Difco. B 62), na proporção de 0,2 para $0,3 \mathrm{ml}$, respectivamente.

Foram consideradas positivas sòmente as amostras capazes de coagular totalmente o plasma, dentro do limite de 3 horas de incubaçāo em banho-maria a $37^{\circ} \mathrm{C}$.

4) Fermentação da manita - Para esta prova, o meio utilizado foi água peptonada a $1 \%$ com $1 \%$ de manita e vermelho de fenol, como indicador. A leitura foi feita após 48 horas de incubação a $37^{\circ} \mathrm{C}$.

5) Produção de pigmento - Para esta pesquisa, o germe foi cultivado em meio de Dorset, contendo 1\% de glicose como recomendou DUDGEON \& SIMPSON (1927/28).

Os tubos semeados foram incubados a $37^{\circ} \mathrm{C}$ por 24 horas, e posteriormente mantidos durante 6 dias em temperatura ambiente, quando a leitura foi feita.

6) Fusão da gelatina - Foi observada em meio de gelatina (Difco. B 11) utilizando-se a técnica de semeadura em picada e leitura após permanência por $\mathbf{5}$ dias em temperatura ambiente. Os resultados foram anotados após imersão dos tubos em água gelada.

\section{RESULTADOS}

Os resultados obtidos nas pesquisas realizadas para a verificação do tipo de hemólise, coagulase, produção de pigmento, fermentação da manita e fusāo da gelatina nas amostras de Micrococcus pyogenes, isolados de vacas portadoras de mastite, se acham resumidos na tabela $\mathrm{I}$.

O exame da referida tabela mostra que das 73 amostras estudadas $10,9 \%$ exibiram o fenômeno atribuído à $\alpha$ lisina, $15 \%$ à $\beta, 56,1 \%$ às $\alpha \beta$ lisinas e $17,8 \%$ não apresentaram hemólise. 
Quadro I - Caracteristicas das amostras distribuidas de acôrdo com o respectivo comportamento em placa de agar-sangue.

\begin{tabular}{|c|c|c|c|c|c|c|c|c|c|}
\hline \multirow{2}{*}{$\begin{array}{c}\begin{array}{c}N^{\circ} \mathrm{de} \\
\text { amostras }\end{array} \\
8\end{array}$} & \multirow{2}{*}{$\begin{array}{c}\begin{array}{c}\text { Tipo de hemó- } \\
\text { lise }\end{array} \\
\text { Alfa hem. .... }\end{array}$} & \multicolumn{2}{|c|}{$\begin{array}{l}\text { Coagulase } \\
+\quad-\end{array}$} & \multicolumn{2}{|c|}{$\begin{array}{c}\text { Pigmento } \\
\text { Albus Aureus }\end{array}$} & \multicolumn{2}{|c|}{+ Manita } & \multicolumn{2}{|c|}{$\begin{array}{l}\text { Gelatina } \\
+\end{array}$} \\
\hline & & 8 & 0 & 2 & 6 & 8 & 0 & 7 & 1 \\
\hline 11 & Beta hem. .... & 10 & 1 & 11 & 0 & 11 & 0 & 7 & 4 \\
\hline 41 & Alfa-Beta hem. & 41 & 0 & 37 & 4 & 41 & 0 & 40 & 1 \\
\hline 13 & Não hem. & 6 & 7 & 11 & 2 & 5 & 8 & 4 & 9 \\
\hline
\end{tabular}

A produção da coagulase foi evidenciada em $89 \%$ das amostras estudadas.

Com relação à produção de pigmento, $16,4 \%$ pertenciam à varicdade aureus e $83,5 \%$ à variedade albus. A maioria das amostras coagulase positivas e que, em placa de agar-sangue exibiram algum grau de hemólise, pertencia à variedade albus.

As amostras fermentadoras da manita incluem tôdas as coagulases positivas e formadoras de toxina e $38,4 \%$ das não hemolíticas.

Com relaçāo à fusāo da gelatina as amostras estudadas mostraram atividade em $79,4 \%$ dos casos. lisinas.

A tabela II resume os resultados obtidos nas dosagens de hemo-

As dosagens das hemolisinas com glóbulos de coelho deram um titulo geralmente elevado na primeira leitura, mas que pouco progredia após refrigeração por uma noite. Por outro lado, com glóbulos de carneiro, na primeira leitura a hemólise produzida foi menor do que aquela observada com glóbulos de coelho, porém, estendeu-se a altas diluições, após refrigeração.

\section{DISCUSSAO}

Conforme GlenNy e Stevens (1935) demonstraram, no minimo duas diferentes toxinas designadas por êles $\alpha$ e $\beta$ lisinas, podem ser produzidas pelos estafilococos.

Uma toxina ativa a $37^{\circ} \mathrm{C}$ sôbre glóbulos de coelho e manifestando alguma ação sôbre glóbulos de carneiro, recebeu o nome de a lisina. Uma segunda toxina inativa sôbre glóbulos de coelho, mas, ativa sôbre 
QUADRO II - DOSAGENS DAS HEMOLISINAS $\alpha$ E $\beta$

Titulo hemolitico contra glóbulos de coelho

\begin{tabular}{|c|c|c|c|c|c|c|c|c|c|c|c|c|c|c|}
\hline \multirow{2}{*}{$\begin{array}{c}\mathrm{N}^{\circ} \mathrm{de} \\
\text { amostras }\end{array}$} & \multirow{2}{*}{ Tipo de hemölise } & \multicolumn{13}{|c|}{ Diluiçāo da toxina } \\
\hline & & $1 / 1$ & $1 / 5$ & $1 / 10$ & $1 / 20$ & $1 / 40$ & $1 / 80$ & $1 / 100$ & $1 / 200$ & $1 / 300$ & $1 / 400$ & $1 / 600$ & $1 / 800$ & $1 / 1200$ \\
\hline 8 & Alfa hem. ..... & - & - & - & 1 & - & - & 3 & - & - & 2 & - & 1 & 1 \\
\hline 11 & Beta hem. & - & - & 2 & - & - & 4 & 1 & - & 2 & - & 2 & 一 & - \\
\hline 41 & Alfa-Beta hem. . & - & - & - & 3 & 1 & 2 & 5 & 4 & 6 & 13 & 2 & 3 & 2 \\
\hline
\end{tabular}

Título hemolitico contra glóbulos de carneiro

\begin{tabular}{|c|c|c|c|c|c|c|c|c|c|c|c|c|c|c|}
\hline \multirow{2}{*}{$\begin{array}{c}\mathrm{N}^{0} \mathrm{de} \\
\text { amostras }\end{array}$} & \multirow{2}{*}{ Tipo de hemólise } & \multicolumn{13}{|c|}{ Diluição da toxina } \\
\hline & & $1 / 1$ & $1 / 5$ & $1 / 10$ & $1 / 20$ & $1 / 40$ & $1 / 80$ & $1 / 100$ & $1 / 200$ & $1 / 300$ & $1 / 400$ & $1 / 600$ & $1 / 800$ & $1 / 1200$ \\
\hline 8 & Alfa hem. ..... & 2 & - & - & 3 & - & - & 一 & - & - & - & - & - & - \\
\hline 11 & Beta hem. ... & - & - & - & 1 & 一 & 2 & 4 & - & - & 3 & 1 & - & - \\
\hline 41 & Alfa-Beta hem. . & - & - & - & 2 & - & 2 & 3 & 1 & 4 & 9 & 4 & 10 & 6 \\
\hline
\end{tabular}

A leitura do título final foi feita após 1 hora em banho-maria a $37^{\circ} \mathrm{C}$, seguida de refrigeraçāo por uma noite. 
glóbulos de carneiro após incubação a $37^{\circ} \mathrm{C}$ seguida de incubação a baixa temperatura, foi designada como $\beta$ lisina.

Posteriormente MINETT (1937), estudando o comportamento dos estafilococos hemolíticos em placa de agar-sangue de bovino e carneiro, observou que nas amostras produtoras de a lisina, um extenso halo claro de hemólise total se desenvolvia ao redor da colônia, quando a placa era incucaba a $37^{\circ} \mathrm{C}$. Aquelas amostras que produziam $\beta$ lisina exibiam um halo escuro de hemólise parcial, que se manifestava após incubação a $37^{\circ} \mathrm{C}$ seguida de refrigeração.

Este autor verificou, ainda, que algumas amostras produziam tanto a a como a $\beta$ lisina. Em tais casos, após incubação a 37 C por 48 horas, uma zona clara circundava a colônia e era por seu turno envolvida por um halo escuro. Quando a placa era refrigerada, a zona escura gradualmente se tornava clara, sem contudo atingir o grau exibido na zona correspondente à $\alpha$ lisina e uma terceira zona de hemólise parcial, escura, agora se manifestava.

No presente trabalho, com amostras isoladas de vacas portadoras de mastite, as zonas de hemólise foram estudadas em agar-sangue de carneiro e os resultados obtidos foram superponiveis aos observados por MinetT.

Entretanto, a titulaçāo dessas hemolisinas permitiu observar que nos casos em que o aspecto da placa de agar-sangue indicava sòmente produção da $\beta$ lisina, o filtrado se mostrava ativo em grau variảvel para glóbulos de coelho, demonstrando, assim, a presença da a lisina.

Dá concluirmos que a presença ou ausência de uma zona clara de hemólise total em placa de agar sangue de carneiro, não nos parece ser uma indicação relevável da capacidade da amostra de produzir a lisina, pois, que algumas amostras que em placa nāo produziram uma zona clara de hemólise bem definida, demonstraram, posteriormente, serem produtoras de $\alpha$ lisina em título elevado.

$\mathrm{Na}$ maioria das amostras que exibiram em placa de agar sangue uma dupla zona de reação $\alpha \beta$, o filtrado revelou predominância quantitativa da $\beta$ lisina, conforme se depreende do exame da tabela II.

Em tôdas as amostras classificadas como inertes em placa, não foi evidenciada nem $\alpha$ nem $\beta$ lisina, no filtrado.

Blair (1939), em uma revisāo dos estafilococos patogênicos, estabeleceu que, de acôrdo com sua experiência, a reação da coagulase pode ser tomada como indice bastante suficiente da potencialidade patogênica dos estafilococos. 
Dubos (1952), refere-se à prova da coagulase, usando plasma de coelho, como o mais relevável critério "in vitro" para determinação dos estafilococos patogênicos.

Verificámos, com plasma oxalatado de coelho, que as amostras por nós estudadas se comportaram em sua maioria como coagulase positivas.

Plastridge (1939) observou que há pouca correlaçāo entre a habilidade dos estafilococos para produzir pigmento, e seu papel irritativo sôbre o úbere.

Os resultados por nós obtidos revelaram que as amostras coagulase positivas eram geralmente do tipo albus.

A fermentaçāo da manita não se correlata bem com o teste da coagulase e produção de toxina. A totalidade das amostras coagulase positivas e formadoras de toxina fermentaram a manita, mas, várias amostras que eram coagulase negativas e não toxigênicas, também a fermentaram. A fusão da gelatina não foi caracteristica constante dos estafilococos estudados.

\section{SUMARIO E CONCLUSÖES}

Foram estudadas 73 amostras de Micrococcus pyogenes de vacas portadoras de mastite, tendo sido pesquisadas simultâneamente a produção de hemolisinas, coagulação do plasma oxalatado, fermentação da manita, produção de pigmento e fusão da gelatina.

Verificou-se que um número significativo de amostras foi capaz de produzir $\alpha \beta$ lisinas.

Nāo foi possivel obter uma $\beta$ toxina pura, pois, quando o exame da placa indicava sòmente produçāo de $\beta$ lisina, o filtrado continha também a $\alpha$ lisina.

Das amostras hemoliticas pràticamente tôdas foram coagulase positivas.

A maioria dos estafilococos estudados pertencia à variedade albus.

A fermentação da manita foi evidenciada em tôdas as amostras coagulase e toxina positivas.

Quanto à fusão da gelatina não obtivemos dados concordantes com as demais provas.

Os dados obtidos foram discutidos à luz da literatura especializada. 


\section{SUMMARY AND CONCLUSIONS}

Seventy-three specimens of Micrococcus pyogenes from cows with mastitis were studied. The production of hemolysins, coagulation of oxalated plasma, fermentation of manitol pigmentation and fusion of gelatin were serched simultaneously.

It was verified that a significative number of specimens were able to produce $\alpha \beta$ lysins.

It was not possible to obtain pure $\beta$ toxin. In the case that the plate culture suggested only the presence of $\beta$ lysin, the filtrate exibited also $\alpha$ lysin.

The hemolitic strain were all positive to the coagulase test.

All the strain were of albus type. Fermentation of manitol was showed in all coagulase positive and toxin producing strains.

The results obtained were discussed.

\section{BIBLIOGRAFIA}

BlaIR, J. E. - 1939 - The Pathogenic Staphylococci. Bact. Rev., 3:97

Dolmann, C. E. \& Kitching, G. S. - 1935 - Tests for inocuity and antigenic potency of staphylococcus toxoid. Jour. Path. and Bact., 41(1):137-62

Dusos, R. J. - 1952 - Bacterial and mycotic infections of mand. $2^{\text {nd }}$ ed.:358-77, Philadelphia, J. B. Lippincott Co.

Dudgeon, L. S. \& Simpson, J. W. H. - Cit. Minett - 1936

GlenNy, A. T. \& Stevens, M. F. - 1935 - Staphylococcus toxine and antitoxins. Jour. Path. and Bact., 40(2):201-10

Mac Farland, A. M. - Cit. Selbie, F. R. \& Simon, R. D. - 1952 - Virulence to mice of staphylococcus pyogenes: its measurement and its relations to certain in vitro properties. Brit. Jour. Exp. Path., 38(4):315-26

MINETT, F. C. - 1936 - Staphylococci from animal with particular reference to toxins production. Jour. Comp. Path. and Bact., $42: 247$

Minetr, F. C. - 1937 - Studies on bovine mastitis. XII. Mastitis due to staphylococci. Jour. Comp. Path. and Therap., $50(2): 101-21$

Plastridge, W. N. - Anderson, E. O. - Williams, L. F. \& Weirether, F. J. 1939 - Infections Bovine Mastitis 7 characteristics of Udder Staphylococci. Boull. 231 Storrs Agricultural Exper. Sta. Univ. of Conn., Storrs. Conn.

Thompson, R. \& KorozA, D. - 1937 - Correlated antigenic and biochemical properties of Staphylococci. Jour. Bact., $34: 69-71$ 